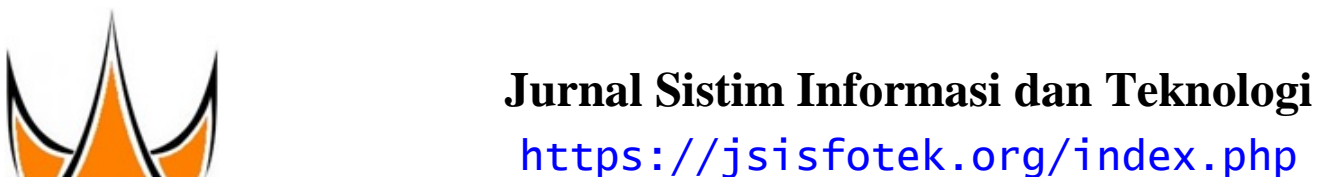

\title{
Simulasi Jenis Penyakit Pasien yang Berobat Menggunakan Metode Monte Carlo
}

\author{
Romia Lubis ${ }^{1 凶}$ \\ ${ }^{1}$ Independent Researcher \\ romialubis18@gmai1.com
}

\begin{abstract}
The Community Health Center (Puskesmas) is a functional health organization in providing comprehensive and integrated services to the community. This organization is a community health development center that fosters community participation in improving public health services funded by the government. As the first health facility in providing health services, the Puskesmas is often visited by many patients who arrive at the same time. The number of patient visits that are too many is inversely proportional to the health workers who are on duty. This causes the ongoing health services to be less than optimal. To improve these services, identification of the type of disease is carried out so that better services can be prepared. The purpose of this study is to predict the type of disease in the future. The data on the types of diseases that were processed in this study from 2019 to 2021 were sourced from the Silaping Health Center. The data is processed by the Monte Carlo method. The results of this study are predictions of types of diseases in the future tend to increase every month, so that the Puskesmas must prepare more medical personnel who have expertise in their fields. This information can be used as a reference in the application of manpower to higher institutions to improve services. Thus, this system is very helpful in improving services by making it easier to identify needs for the future.
\end{abstract}

Keywords: Simulation, Health Center, Type of Disease, Patient, Monte Carlo Method.

\begin{abstract}
Abstrak
Pusat Kesehatan Masyarakat (Puskesmas) merupakan suatu organisasi kesehatan fungsional dalam memberikan pelayanan secara menyeluruh dan terpadu kepada masyarakat. Organisasi ini merupakan pusat pengembangan kesehatan masyarakat yang membina peran serta masyarakat dalam meningkatkan pelayanan kesehatan masyarakat yang didanai oleh pemerintah. Sebagai fasilitas kesehatan pertama dalam memberikan pelayanan kesehatan maka Puskesmas sering dikunjungi oleh banyak pasien yang berdatangan dalam waktu bersamaan. Jumlah kunjungan pasien yang terlalu banyak maka berbanding terbalik dengan tenaga kesehatan yang sedang bertugas. Hal ini menyebabkan pelayanan kesehatan yang berlangsung menjadi kurang optimal. Untuk meningkatkan pelayanan tersebut maka dilakukan identifikasi jenis penyakit sehingga dapat dipersipakan pelayanan yang lebih baik lagi. Tujuan penelitian ini adalah untuk memprediksi jenis penyakit dimasa yang akan datang. Data jenis penyakit yang diolah dalam penelitian ini dari tahun 2019 sampai 2021 yang bersumber dari Puskesmas Silaping. Data diolah dengan metode Monte Carlo. Hasil dari penelitian ini adalah prediksi jenis penyakit dimasa akan datang cenderung meningkat setiap bulannya, sehingga pihak Puskesmas harus lebih banyak mempersiapkan tenaga medis yang mempunyai keahlian dibidangnya. Informasi ini dapat dijadikan rujukan dalam pengajuaan tenaga ke induk instasi yang lebih tinggi untuk meningkatkan pelayanan. Sehingga, sistem ini sangat membantu dalam meningkatkan pelayanan dengan mempermudah mengidentifikasi kebutuhan untuk masa yang akan datang.
\end{abstract}

Kata kunci: Simulasi, Puskesmas, Jenis Penyakit, Pasien, Metode Monte Carlo.

JSISFOTEK is licensed under a Creative Commons 4.0 International License.

\section{$(\mathrm{cc}) \mathrm{Br}$}

\section{Pendahuluan}

Pusat Kesehatan Masyarakat (Puskesmas) merupakan suatu organisasi kesehatan fungsional, yang merupakan pusat pengembangan kesehatan masyarakat yang juga membina peran serta masyarakat disamping memberikan pelayanan secara menyeluruh dan terpadu kepada masyarakat. Puskesmas merupakan unit kesehatan yang didanai oleh pemerintah dan merupakan unit yang mejadi rujukan masyarakat dalam melakukan pemeriksaan kesehatan [1].
Puskesmas mempunyai tugas melaksanakan kebijakan kesehatan untuk mecapat tujuan pembangunan kesehatan diwilayah kerjanya dalam rangka mendukung terwujudnya kecematan sehat.

Sebagai fasilitas kesehatan pertama dalam memberikan pelayanan kesehatan dalam suatu wilayah kerja, Puskesmas sering dikunjungi oleh banyak pasien yang datang berbagai macam jenis penyakit yang diderita pasien. Jumlah jenis penyakit pasien yang terlalu banyak tersebut terkadang berbanding terbalik dengan tenaga kesehatan yang sedang bertugas, hak ini menyebabkan pelayanan kesehatan yang berlangsung menjadi kurang optimal. 
Model merupakan suatu uraian yang digambarkan karena tidak dapat dilihat secara langsung. Pada umumnya model diartikan sebagai suatu gambaran sistem nyata yang sedang berlangsung. Sistem nyata adalah sisten yang sedang berlangsung di dunia nyata dan menjadi fokus persoalan yang sedang diteliti [2]. Pendekatan simulasi harus diawali dengan pembangunan model sistem nyata, model tersebut harus dapat menunjukkan bagaimana berbagai komponen dalam sistem saling berinteraksi sehingga benar-benar menggambarkan perilaku sistem. Setelah model dibuat maka model tersebut ditransformasikan ke dalam program komputer sehingga memungkinkan untuk disimulasikan [3]. Peramalan atau prediksi merupakan dugaan terhadap suatu permintaan yang akan datang pada beberapa variabel peramalan berdasarkan data masa lampau [4].

Dengan memberikan informasi prediksi tentang jenis penyakit pasien yang berobat dan menerapkan metode Monte Carlo untuk memprediksi jumlah jenis penyakit pasien yang berobat yang tepat di Puskesmas dengan bantuan sistem, yang menerapkan metode Monte Carlo ke dalam bahasa pemrograman PHP untuk memprediksi jenis penyakit dimasa akan datang. Proses simulasi dapat memanfaatkan data lama yang menggambarkan hubungan sebab dan akibat dari sebuah sistem model komputer, sehingga mampu menggambarkan pada sistem nyata. Pengguna simulasi seringkali mengarah pada hasil yang optimal maupun mendekati optimal [5]. Metode yang dapat digunakan adalah monte carlo. Monte carlo merupakan kumpulan angka yang diartikan sebagai metode simulasi statistik [6].

Pada dasar, simulasi dapat diaplikasi untuk mengatasi masalah-masalah komputasi yang melibatkan variabelvariabel acak. Monte carlo diaplikasikan pada program untuk memperkirakan penanda kinerja tertentu dari sistem dunua nyata [7]. Simulasi Monte Carlo merupakan sebuah metode atau cara analisis yang berpatokan dengan nilai data-data acak. Hasil proses ini menghasilkan sebuah statistik probabilitas. Selanjutnya, hasil ini digunakan untuk memahami dampak sebuah ketidak pastian. Pengguna dari monte carlo sendiri sudanh sangat berkembang dalam bidang evaluasi proyek, manajen proyek, analisa biaya, lainnya [8].

Simulasi Monte Carlo atau disebut juga denga cride Monte Carlo. Sebutan ini merupakan suatu metode yang melibatbatkan pembangkit dengan menggunakan bilangan acak dengan bantuan distibusi probabilitas yang dapat diketahui dan ditentukan. Dasar dari simulasi Monte Carlo adalah melakukan percobaan pada elemen-elemen probabilitas melalui pengambilan secara acak [9]. Dari latar belakang yang telah dijelaskan dapat disimpulkan bawha, Menerapkan metode Monte Carlo dapat membantu untuk memprediksi jenis penyakit dimasa yang akan datang lebih optimal.

\section{Metodologi Penelitian}

Agar penelitian berjalan dengan baik, maka diperlukan kerangka kerja dari penelitian. Kerangka penelitian merupakan tahapan-tahapan yang dilakukan dalam menyelesaikan penelitian. Adapun kerangka kerja penelitian dapat dilihat pada Gambar 1 .

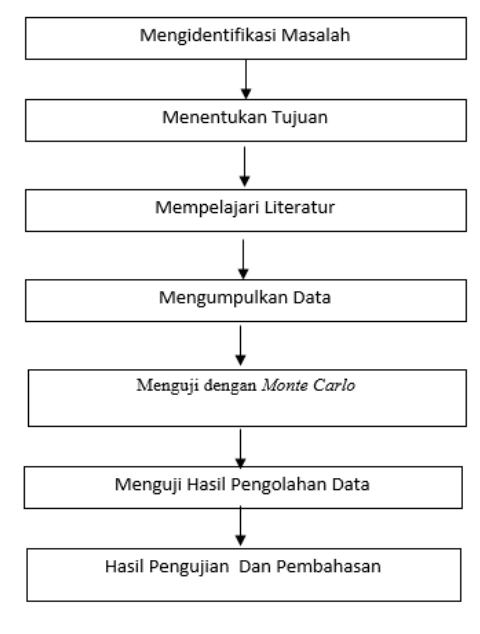

Gambar 1. Kerangka Kerja Penelitian

\subsection{Mengidentifikasi Masalah}

Tahap ini merupakan tahap awal untuk menentukan permasalah sebelum melakukan penelitian pada objek penelitian. Dengan mencari sumber informasi masalah pada objek penelitian untik mencari penyelesaian berkaitan dengan permasalahan. Sehingga dapat menguraikan masalah dan memudahkan langkah dalam menyelesaikan masalah.

\subsection{Menentukan Tujuan}

Tujuan penelitian adalah suatu hal yang akan dicapai dalam suatu penelitian yang dilakukan. Tujuan penelitian merupakan hasil akhir ideal yang diharapkan tercapai setelah penelitian tersebut dilakukan. Tujuan penelitian harus ditentukan diawal terlebih dahulu sebelum penelitian dilakukan. Menentukan tujuan penelitian sangat diperlukan agar penelitian yang dilakukan bermanfaat bagi penggunanya.

\subsection{Mempelajari Literatur}

Untuk mencapai tujuan maka dipelajari beberapa literatur-literatur yang diperkirakan dapat digunakan. Kemudian literatur-literatur yang dipelajari tersebut diseleksi dan dipilih literatur mana yang akan digunakan dalam penelitian. Literatur diambil dari berbagai sumber yaitu berupa artikel, jurnal ilmiah tentang simulasi Monte Carlo, serta bahan bacaan lain yang mendukung.

\subsection{Mengumpulkan Data}

Mengumpulkan data adalah tindakan yang dilakukan untuk mengumpulkan semua data-data yang 
diperlukan dalam penelitian. Pengumpulan data dalam penelitian ini menggunakan data sekunder yaitu penelusuran terhadap dokumen-dokumen yang ada untuk mendapatkan data tentang jenis penyakit pasien dimasa lampau pada Puskesmas Silaping.

\subsection{Menguji Data dengan Monte Carlo}

langkah-langkah mengelola data dengan Monte Carlo adalah:

\section{a. Membuat Distribusi Probabilitas}

Distribusi Probabilitas menggambarkan peluang dari variabel yang ada. Nilai probabilitas dapat diperoleh dengan cara membagi frekuensi dengan total frekuensi. Rumus distribusi probabilitas disajikan pada Persamaan (1).

$$
P=\frac{F}{J}
$$

Dimana $p$ merupakan distribusi probabilitas menggambarkan peluang dari variabel yang ada. $F$ adalah frekuensi sedangkan $J$ adalah total atau jumlah keseluruhan dari frekuensi.

\section{b. Membangun Distribusi Probabilitas Kumulatif}

Distribusi probabilitas kumulatif diperoleh dari hasil penjumlahan nilai distribusi probabilitas dengan jumlah nilai distribusi probabilitas sebelumnya, kecuali untuk nilai distribusi probabilitas kumulatif yang pertama. Di mana nilai probabilitas kumulatifnya sama dengan nilai probabilitas variabel itu sendiri.

\section{c. Pembentukan Interval Angka Random (Angka Acak).}

Interval angka acak dibentuk berdasarkan nilai distribusi probabilitas kumulatif yang telah diperoleh pada tahap sebelumnya. Penetapan angka acak dilakukan untuk setiap variabel, penggunaan interval angka acak berfungsi sebagai pembatas antara variabel yang satu dengan variabel yang lain dan juga memberikan acuan hasil simulasi dari percobaan berdasarkan angka acak yang dibangkitkan.

\section{d. Membangkitkan Angak Random (Angka Acak)}

Setelah interval angka random dibentuk, selanjutnya pada tahap ini akan dibangkitkan angka random yang akan digunakan dalam simulasi. Untuk membangkitkan angka random, terdapat 2 metode yang biasa digunakan yaitu Mixed Congruent Method dan Multiplicative Method. pada penelitian ini angka random akan dibangkitkan dengan menggunakan metode Mixed Congruent Method dengan menggunakan Persamaan (2).

$$
\mathrm{Z}_{\mathrm{i}+1}=\left(\mathrm{a} * \mathrm{Z}_{\mathrm{i}}+\mathrm{c}\right) \bmod \mathrm{m}
$$

Dimana a merupakan konstanta pengali kecil dari konstanta modulus, sedangakan c adalah konstanta pergeseran kecil dari konstanta modulus, m adalah konstanda modulud besar dari $\mathrm{n} 0, \mathrm{Zi}$ bilangan awal (bilangan bulat $\geq 0, \mathrm{ZO}<\mathrm{m}$ )

e. Membangkitkan angka random dengan Mixed Congruent Method membutuhkan.

Membuat Simulasi Dari Rangkaian Percobaan Simulasi dilakukan dengan cara memasukkan dan membandingkan angka random yang telah dibangkitkan.

\subsection{Pengujian Hasil Pengolahan Data}

Pada tahap ini, peneliti melakukan pengujian setelah mendapatkan data guna mengetahui apakan data yang diolah teleh sesuai dengan tujuan yang diharapkan.

\section{Hasil dan Pembahasan}

Pengolahan data simulasi untuk memprediksi jenis penyakit pasien yang berobat dengan menggunakan Metode Monte Carlo adalah sebagai berikut:

\subsection{Data Jumlah Jenis Penyakit Tahun 2019}

Data yang digunakan untuk memprediksi jenis penyakit pasien pada tahun 2019, 2020, dan 2021 pada Tabel 1.

Tabel 1. Data jenis Penyakit Tahun 2019-2021

\begin{tabular}{lccr}
\hline Bulan & 2019 & 2020 & 2021 \\
\hline January & 115 & 406 & 317 \\
February & 168 & 286 & 368 \\
Maret & 100 & 521 & 321 \\
April & 140 & 370 & 334 \\
Mei & 115 & 421 & 189 \\
Juni & 186 & 411 & 294 \\
Juli & 502 & 375 & 359 \\
Agustus & 500 & 433 & 324 \\
September & 536 & 489 & 315 \\
Oktober & 413 & 187 & 321 \\
November & 256 & 299 & 273 \\
Desember & 377 & 260 & 316 \\
\hline Total & 3.408 & 4.458 & 3.731 \\
\hline
\end{tabular}

\subsection{Menentukan Distribusi Probabilitas}

Data yang digunakan untuk memprediksi jenis penyakit pasien pada tahun 2019, 2020, dan 2021 pada Tabel 1.

Tabel 2 menyajikan perhitungan distribusi probabilitas berdasarkan data yang ditampilkan pada Tabel 1 .

Tabel 2. Distribusi Probabilitas

\begin{tabular}{lccc}
\hline Bulan & 2019 & 2020 & 2021 \\
\hline Januari & 0,030 & 0,090 & 0,080 \\
Februari & 0,040 & 0,060 & 0,100 \\
Maret & 0,020 & 0,110 & 0,080 \\
April & 0,040 & 0,080 & 0,080 \\
Mei & 0,030 & 0,090 & 0,050 \\
Juni & 0,050 & 0,090 & 0,110 \\
Juli & 0,140 & 0,080 & 0,090 \\
Agustus & 0,140 & 0,090 & 0,080 \\
September & 0,150 & 0,100 & 0,080 \\
Oktober & 0,120 & 0,040 & 0,080 \\
November & 0,070 & 0,060 & 0,070 \\
Desember & 0,011 & 0,050 & 0,080 \\
\hline Total & 1,340 & 1,340 & 1,380 \\
\hline
\end{tabular}


Perhitungan Distribusi Probabilitas didapatkan dari jumlah perbulan dibagi dengan total setiap tahun begi sampai seterusnya.

\subsection{Menentukan Distribusi Probabilitas Kumulatif}

Hasil perhitungan distribusi kumulatif yang disajikan pada Tabel 3.

Tabel 3. Distribusi Probabilitas

\begin{tabular}{lcccccr}
\hline Bulan & \multicolumn{3}{c}{ Distribusi Probabilitas } & \multicolumn{3}{c}{ Probabilitas Kumulatif } \\
\hline & 2019 & 2020 & 2021 & 2019 & 2020 & 2021 \\
\hline Jan & 0,03 & 0,09 & 0,08 & 0,03 & 0,09 & 0,08 \\
Feb & 0,04 & 0,06 & 0,10 & 0,07 & 0,15 & 0,18 \\
Maret & 0,02 & 0,11 & 0,08 & 0,09 & 0,26 & 0,26 \\
April & 0,04 & 0,08 & 0,08 & 0,13 & 0,34 & 0,34 \\
Mei & 0,03 & 0,09 & 0,05 & 0,16 & 0,43 & 0,39 \\
Juni & 0,05 & 0,09 & 0,11 & 0,21 & 0,52 & 0,50 \\
Juli & 0,14 & 0,08 & 0,09 & 0,35 & 1,00 & 0,59 \\
Agus & 0,14 & 0,09 & 0,08 & 0,49 & 1,09 & 1,07 \\
Sept & 0,15 & 0,10 & 0,08 & 1,04 & 1,19 & 1,15 \\
Okto & 0,12 & 0,04 & 0,08 & 1,16 & 1,23 & 1,23 \\
nov & 0,07 & 0,06 & 0,07 & 1,23 & 1,29 & 1,30 \\
Des & 0,11 & 0,05 & 0,08 & 1,34 & 1,34 & 1,38 \\
\hline Total & 1,34 & 1,34 & 1,38 & - & - & - \\
\hline
\end{tabular}

\subsection{Menentukan Interval Angka Acak}

\begin{tabular}{lllll} 
Agustus & 324 & 1,09 & 101 & 109 \\
September & 489 & 1,19 & 110 & 119 \\
Oktober & 187 & 1,23 & 120 & 123 \\
November & 299 & 1,29 & 124 & 129 \\
Desember & 260 & 1,34 & 130 & 134 \\
\hline
\end{tabular}

Tabel 6. Interval Bilangan Acak Tahun 2021

\begin{tabular}{lllrr}
\hline \multirow{2}{*}{ Bulan } & Jumlah & $\begin{array}{c}\text { Probabilitas } \\
\text { Kumulatif }\end{array}$ & \multicolumn{2}{c}{$\begin{array}{c}\text { Interval Angka } \\
\text { Random }\end{array}$} \\
\cline { 4 - 5 } & & & Awal & Akhir \\
\hline Januari & 317 & 0,08 & 1 & 8 \\
Februari & 386 & 0,18 & 9 & 18 \\
Maret & 321 & 0,26 & 19 & 26 \\
April & 334 & 0,34 & 27 & 34 \\
Mei & 189 & 0,39 & 35 & 39 \\
Juni & 411 & 0,50 & 40 & 50 \\
Juli & 359 & 0,59 & 51 & 59 \\
Agustus & 324 & 1,07 & 60 & 107 \\
September & 315 & 1,15 & 108 & 115 \\
Oktober & 321 & 1,23 & 116 & 123 \\
November & 273 & 1,30 & 124 & 130 \\
Desember & 316 & 1,38 & 131 & 138 \\
\hline
\end{tabular}

\subsection{Membangkitkan angka acak}

Membangkitkan angka random dengan Mixed Congruent Method membutuhkan 4 parameter yang Berikut cara menetapkan nilai batasan pada tabel intervallamgka harus ditetapkan terlebih dahulu yaitu a, c, m acak:

dan $\mathrm{Zi}$. Pada tahap ini parameter-parameter di atas selanjutnya akan diisi dengan value $\mathrm{a}=34, \mathrm{c}=90, \mathrm{~m}$

a. Nilai batas awal untuk variabel pertama adalah 1 .

b. Nilai batas akhir diperoleh dengan cara mengalikān 92 nif $_{\mathrm{i}}=22$. Setelah value dari parameter-parameter probabilitas kumulatif masing-masing variabel dengđarsepłoktadiisi, selanjutnya akan dilakukan perhitungan 100.

untuk membangkitkan bilangan acak.

c. Nilai batas awal untuk variabel kedua dan seterusnya dikerghieh hari angka random adalah untuk menentukan dari nilai batas akhir variabel sebelumnya kempdiankinan dari hasil simulasi. Angka random dapat ditambahkan dengan angka 1 .

Hasil penentuan interval bilangan acak disajikan pada Tabel 4, Tabel 5, dan Tabel 6.

Tabel 4. Interval Bilangan acak Tahun 2019

\begin{tabular}{lllll}
\hline \multirow{2}{*}{ Bulan } & Jumlah & $\begin{array}{c}\text { Probabilitas } \\
\text { Kumulatif }\end{array}$ & \multicolumn{2}{c}{$\begin{array}{c}\text { Interval Angka } \\
\text { Random }\end{array}$} \\
\cline { 4 - 5 } & & & Awal & akhir \\
\hline Januari & 115 & 0,03 & 1 & 3 \\
Februari & 168 & 0,07 & 4 & 7 \\
Maret & 100 & 0,09 & 8 & 9 \\
April & 140 & 0,13 & 10 & 13 \\
Mei & 115 & 0,16 & 14 & 16 \\
Juni & 186 & 0,21 & 17 & 21 \\
Juli & 502 & 0,35 & 22 & 35 \\
Agustus & 500 & 0,49 & 36 & 49 \\
September & 536 & 1,04 & 50 & 104 \\
Oktober & 413 & 1,16 & 105 & 116 \\
November & 256 & 1,23 & 117 & 123 \\
Desember & 377 & 1,34 & 124 & 134 \\
\hline
\end{tabular}

Tabel 5. Interval Bilangan Acak Tahun 2020

\begin{tabular}{|c|c|c|c|c|}
\hline \multirow[t]{2}{*}{ Bulan } & \multirow[t]{2}{*}{ Jumlah } & \multirow{2}{*}{$\begin{array}{c}\text { Probabilitas } \\
\text { Kumulatif }\end{array}$} & \multicolumn{2}{|c|}{$\begin{array}{c}\text { Interval Angka } \\
\text { Random }\end{array}$} \\
\hline & & & Awal & Akhir \\
\hline Januari & 460 & 0,09 & 1 & 9 \\
\hline Februari & 286 & 0,15 & 10 & 15 \\
\hline Maret & 521 & 0,26 & 16 & 26 \\
\hline April & 370 & 0,34 & 27 & 34 \\
\hline Mei & 421 & 0,43 & 35 & 43 \\
\hline Juni & 295 & 0,52 & 44 & 52 \\
\hline Juli & 375 & 1,00 & 53 & 100 \\
\hline
\end{tabular}
mempengaruhi hasil simulasi, dimana simulasi itu sendiri merupakan bentuk representatif dari kondisi ketidakpastian yang terjadi pada kondisi sebenarnya. Jika ditampilkan dalam bentuk tabel, angka-angka random yang telah dibangkitkan di atas akan terlihat seperti Tabel 7.

Tabel 7. Angka acak

\begin{tabular}{cccccr}
\hline \multirow{2}{*}{ Index ke-1 } & \multicolumn{3}{c}{ Variabel } & $\begin{array}{r}\text { Angka Acak } \\
(\mathrm{Zi}+1)\end{array}$ \\
\cline { 2 - 5 } $\mathrm{A}$ & $\mathrm{Zi}$ & $\mathrm{C}$ & $\mathrm{M}$ & 10 \\
2 & 34 & 22 & 90 & 92 & 62 \\
3 & 34 & 10 & 90 & 92 & 82 \\
4 & 34 & 62 & 90 & 92 & 26 \\
5 & 34 & 82 & 90 & 92 & 54 \\
6 & 34 & 26 & 90 & 92 & 86 \\
7 & 34 & 54 & 90 & 92 & 70 \\
8 & 34 & 70 & 90 & 92 & 78 \\
9 & 34 & 78 & 90 & 92 & 74 \\
10 & 34 & 74 & 90 & 92 & 30 \\
11 & 34 & 30 & 90 & 92 & 6 \\
12 & 34 & 6 & 90 & 92 & 18 \\
\hline
\end{tabular}

Berdasarkan Tabel 7 didapatkan angka acak sebanyak 12 adalah 10, 62, 82, 26, 54, 86, 70, 78, 74, 30, 6, 18. Bilangan tersebut akan dijadikan untuk memprediksi jenis penyakit.

\subsection{Hasil Simulasi}


Hasil dari percobaan simulasi prediksi data tahun 2019 akan digunakan untuk memprediksi pada tahun 2020 yang diolah berdasarkan simulasi. Hasil prediksi disajikan pada Tabel 8.

Tabel 8. Hasil Simulasi

\begin{tabular}{llcc}
\hline Bulan & Jumlah & ilangan Acak & Prediksi \\
\hline Januari & 460 & 10 & 286 \\
Februari & 286 & 62 & 375 \\
Maret & 521 & 82 & 375 \\
April & 370 & 26 & 321 \\
Mei & 421 & 54 & 359 \\
Juni & 295 & 86 & 324 \\
juli & 375 & 70 & 324 \\
Agustus & 324 & 78 & 324 \\
September & 489 & 74 & 324 \\
Oktober & 187 & 30 & 334 \\
November & 299 & 6 & 317 \\
Desember & 260 & 18 & 386 \\
\hline Jumlah & 1.458 & - & 4.049 \\
\hline
\end{tabular}

Hasil simlasi yang disajikan pada Tabel 8 menunjukan peningkatan jenis penyakit pada masa yang akan datang cenderung meningkat setiap bulannya, sehingga pihak Puskesmas harus lebih cepat dalam mempersiapkan tenaga medis yang mempunyai keahlian dibidangnya. Informasi ini dapat dijadikan rujukan dalam pengajuaan tenaga ke induk instasi yang lebih tinggi untuk meningkatkan pelayanan. Sehingga, sistem ini sangat membantu dalam meningkatkan pelayanan dengan mempermudah mengidentifikasi kebutuhan untuk masa yang akan datang

\section{Kesimpulan}

Hasil dari simulasi dalam dengan Metode Monte Carlo telah berhasil memprediksi jumlah jenis penyakit pasien pada Puskesmas Silaping di masa akan datang. Setiap bulan terjadi peningkatan terhadap jenis penyakit sehingga pihak Puskesmas dapat melakukan tindakan dalam mempersiapkan tenaga dalam meningkatkan pelayanan. Sehingga penelitian ini dapat manjadi rujukan dalam melayani masyarakat lebih baik di masa yang akan dating.

\section{Daftar Rujukan}

[1]. Yuniar, E. \& Muslim, M. H. (2018). Sistem
Informasi Layanan Kesehatan Dengan Menggunakan Codeigniter Pada Puskesmas Bululawang. Antivirus J. Ilm. Tek. Inform., 12(1), 1-14, 2018, doi: 10.35457/antivirus.v12i1.429.

[2]. Mahessya, R., Putra, D. \& Veri, J. (2019). Pemodelan Dan Simulasi Penerapan Antrian Multiphase Pada Antrian Pembuatan Sim Pengendara Sepeda Motor Dipolres Sijunjung. $J$. Sains dan Inform., 5(1), 34. doi: 10.22216/jsi.v5i1.4091.

[3]. Hutahaean, M. (2018). Analysis of Distributive Public Policy-Making Model. ICOPOSDev, 141, 119-121. doi: 10.2991/icoposdev-17.2018.25.

[4]. Akbar, Alamsyah, A. H. \& Riska, R. (2020). Simulasi Prediksi Jumlah Mahasiswa Baru Universitas Dehasen Bengkulu Menggunakan Metode Monte Carlo. Pseudocode, 7(1), 8-16. doi: 10.33369/pseudocode.7.1.8-16.

[5]. Zalmadani, H., Santony, J. \& Yunus, Y. (2020). Jurnal Informatika Ekonomi Bisnis Prediksi Optimal dalam Produksi Bata Merah Menggunakan Metode. Inform. Ekon. Bisnis, 2, $1-3$.

[6]. Geni, S. B. Y. \& Santony, J. (2019). Prediksi Pendapatan Terbesar pada Penjualan Produk Cat dengan. J. Inf. Ekon. Bisnis, 1, 15-20.

[7]. Syahrin, E., Santony, J. \& Na'am, J. (2019). Pemodelan Penjualan Produk Herbal Menggunakan Metode Monte Carlo. J. KomtekInfo, 5(3), 33-41. doi: 10.35134/komtekinfo.v5i3.29.

[8]. Wijaya, F. S. \& Sulistio, H. (2019). Penerapan Metode Monte Carlo Pada Penjadwalan Proyek Serpong Garden Apartment. JMTS J. Mitra Tek. Sipil, 2(3), 189. doi: 10.24912/jmts.v2i3.5828.

[9]. Muflihunallah, M., Dharmawan, K. \& Asih, N. M. (2018). Estimasi Nilai Implied Volatility Menggunakan Simulasi Monte Carlo. E-Jurnal Mat., $\quad 239$. 23 Doi: 10.24843/Mtk.2018.V07.I03.P209. 